\title{
Effect of Buckwheat Supplementation on the Quality Parameters of Pasta
}

\section{Tanveer Sultan ${ }^{1}$, Anwaar Ahmed ${ }^{1}$, Aqsa Qayyum ${ }^{2 *}$, Amer Mumtaz ${ }^{2}$ and Naeem Khalid ${ }^{3}$}

${ }^{1}$ Institute of Food and Nutritional Sciences, Pir Mehr Ali Shah Arid Agriculture University Rawalpindi, 46300, Pakistan; ${ }^{2}$ Food Science Research Institute, National Agricultural Research Centre, Islamabad, 44000, Pakistan; ${ }^{3}$ Deputy Secretary (Planning), Department of Agriculture, Government of Punjab Lahore.

\begin{abstract}
The need for nutraceutical and gluten-free food is increasing day by day and buckwheat food products can serve to be a good source to address this demand. In the present study, we investigated the supplementation of buckwheat @ 0\%,10\%,20\%,30\%, 40\% and 50\% in durum wheat to make egg-free pasta of good quality. Rheological studies (dough development time, dough stability, water absorption and mixing tolerance index) were significantly affected $(p \leq 0.05)$ by the supplementation of buckwheat flour. There was a gradual increase in the ash $(0.88 \pm 0.02$ to $1.72 \pm 0.04)$ and fiber contents $(0.01 \pm 0.001$ to $2.64 \pm 0.04)$ with the increment in buckwheat flour while moisture contents decreased significantly $(4.63 \pm 0.04$ to $3.80 \pm 0.04)$. The protein $(8.93 \pm 0.03)$ and fat contents $(3.01 \pm 0.06)$ were significantly higher in supplemented pasta having $50 \%$ buckwheat. However, it negatively influenced the cooking quality parameters (cooking time, loss of solids). The sensory scores emphasized that pasta with $30 \%$ buckwheat supplementation was more appealing for taste, color and texture. The study postulated that buckwheat could be used as a potential source of gluten-free bakery products.

Received | January 25, 2020; Accepted | March 21, 2020; Published | July 28, 2020

*Correspondence | Aqsa Qayyum, Food Science Research Institute, National Agricultural Research Centre, Islamabad, 44000, Pakistan; Email: aqsachatha@gmail.com

Citation | Sultan, T., A. Ahmed, A. Qayyum, A. Mumtaz and N. Khalid. 2020. Effect of buckwheat supplementation on the quality parameters of pasta. Pakistan Journal of Agricultural Research, 33(3): 535-543.

DOI | http://dx.doi.org/10.17582/journal.pjar/2020/33.3.535.543

Keywords | Cooking Quality, Gluten-free, Proximate analysis, Rheological properties, Storage
\end{abstract}

\section{Introduction}

$\mathrm{B}$ uckwheat (Fagopyrum esculentum) belongs to the family Polygonaceae. It is classified as pseudocereal because its grains are practically identical to other cereals like wheat, maize, rice etc. (Liu et al., 2001). The chemical composition of buckwheat is similar and comparable with other cereals. Among various buckwheat varieties, only nine have agricultural and beneficial qualities. Two of these buckwheat species are mostly cultivated throughout the world i.e. common buckwheat (Fagopyrum esculentum) and tartary buckwheat (Fagopyrum tartaricum). In the year 2015, the world production of buckwheat was 2.0 million tonnes. Russia was the leading producer with $43 \%$ of the world production followed by China with 25\% production. In 2017, the production of buckwheat was increased up to $13 \%$ on the globe.

The structure and qualities of buckwheat grain are unique or different in relation to those of wheat grain. It contains a variety of nutraceutical compounds with the potential for functional food development that may provide health benefits beyond basic nutrition (Bonafaccia et al., 2003). Other than being rich in vitamins, especially vitamins B group, higher lysine, iron compounds, copper and magnesium contents 
(Fabjan et al., 2003) buckwheat groats have a high amount of starch (Skrabanja et al., 2004), crude protein,iron, zinc, selenium, polyphenols, and essential amino acids especially lysine, threonine, tryptophan, and also sulfur-containing amino acids (Bonafaccia et al., 2003). In addition, it has been found that buckwheat could be act as a prebiotic food because it could increase lactic acid bacteria in rat intestine (Prestamo et al., 2003). Common Buckwheat seed contains rutin (antioxidant) which has a great effect on the storage of food products without any chemical changes in food products. Buckwheat has been used to reduce the serum glucose level in rats due to its high content of D-chiro inositol, a component of an insulin mediator (Kim et al., 2004).

Utilizing buckwheat in fresh pasta is advantageous as these products minimize the issues which occur at the drying stage. Pasteurization of pasta, using egg as the main ingredient can give good structure to the item. It is most likely known that egg white proteins (albumen) shape the end-product like reticule (bag) which can ensure a cohesive mass with a good consistency; achieved by thermal denaturation even without gluten. Hence, fresh pasta that celiac patients can be able to consume is more attractive from the commercial point of view in the absence of analog products. Buckwheat, which is added as a supplement, can provide beneficial health effects and prevent food from oxidation during processing. Many food ingredients, other than those mentioned above, have been used in pasta production, which increases its diversity, nutrition and product appeal. Pasta is a food product which is mainly made from durum wheat flour, salt and semolina and is consumed all over the world. The objectives of the current research were to investigate the production of buckwheat supplemented pasta and quality evaluation of pasta prepared from the supplemented flour.

\section{Materials and Methods}

Common Buckwheat (Fagopyrum esculentum) was procured from Agricultural Research Center Gilgit Baltistan. Durum wheat, semolina, and wheat flour were procured from the National Agriculture Research Center Islamabad, Pakistan. The samples were cleaned, tempered and subjected to milling using Quadrumate Senior Mill (Model No. 179510, Duisburg) following the standard of AACC (2000). Buckwheat and wheat flour were subjected to chemical analysis. The other materials (salt, oil, Xanthan Gum) were collected from the local market of Islamabad for the preparation of pasta. For further analyses, all the flour samples were mixed in different ratios (given below) in a flour mixer to get the uniform sample.

\section{Rheological study of supplemented flour}

The rheological studies of buckwheat supplemented flour samples were assessed by running samples in Brabender farinograph by the standard procedures of AACC (2000) Method No. 54-21. Buckwheat supplemented flour (BWF) sample was run in farinograph equipped with 50 grams mixing bowl to determine various dough characteristics. The physical properties noted for dough were water absorption, dough development time, and dough stability was obtained from farinograph. Wet and dry gluten contents of supplemented flour were determined as per standard procedure no. 38-12 AACC (2000).

\section{Preparation of pasta}

Flour samples were mixed in dough maker (Model no. $800 \mathrm{~A}-\mathrm{B}, \mathrm{SPAR}$ ) and mixed for 15 minutes to make soft dough for making pasta; the dough was wrapped with wrapping paper and set for 30 minutes. The preparation of pasta wrap paper was removed from dough and a sheet was made from the flour with sheet maker. The cutting of pasta was done by cutter, then pasta was dried at $90{ }^{\circ} \mathrm{C}$ for 6 hours for cooking and sensory analysis. For further analysis pasta samples were dried at $50-55{ }^{\circ} \mathrm{C}$ for 24 hours as described by Rosa et al. (2015). The width was 4-6 $\mathrm{mm}$ and thickness was $0.5 \mathrm{~mm}$. The pasta was stored for further proximate analysis at normal room temperature for 2 months.

\section{Cooking quality of pasta}

The different parameters for cooking of pasta were determined to find the water absorbed and loss of cooking solids etc.

\section{Proximate and sensory analysis of pasta}

Proximate analysis (Moisture, ash, fat, fiber and protein) of supplemented buckwheat flour and pasta was done to find out the quality of pasta AACC (2000). For checking the acceptability of buckwheat supplemented pasta, the sensory analysis was done by panel of five trained judges for parameters of taste, color and texture by a panel of judge as described by Larmond (1977). 
Statistical analysis

All the analyses were carried out in triplicates and subjected to CRD under two factor factorial. All pairwise comparison were carried out using LSD with 95\% confidence interval (Steel et al., 1997).

\section{Results and Discussion}

\section{Rheological study of flour}

Farinographic study of water absorption, dough development time, dough stability, mixing tolerance index significantly differed $(p<0.05)$ among all treatments as shown in Table 2.

The mean values were amplified with an increase in the ratio of buckwheat flour. Baljeet et al. (2010) reported that the water absorption capacity of buckwheat supplemented flour was significantly lower than wheat flour. The weak or lower absorption of water capacity of supplemented buckwheat flour could be ascribed to the existence of minor volume of hydrophilic constituents in buckwheat flour (Akubor and Badifu, 2001). According to the study of Maeda (2004) addition of buckwheat flour above 30\% to wheat flour directly decreases the strength of dough and sensory characteristics. There was a gradual increase in dough development time (DDT) with an increase in percentage of buckwheat flour. The highest value $(10.20 \mathrm{~min})$ was noted in $\mathrm{T}_{5}$ while the lowest value $(5.50 \mathrm{~min})$ was found in $\mathrm{T}_{1}$. Nikolic et al. (2011) observed the extension in dough development time by the addition of buckwheat flour. On the other hand, Gavurnikova et al. (2011) stated that the DDT (time of dough development) gradually decreased after the addition of $20 \%$ of buckwheat or $\geq 10 \%$ of millet. The differences of DDT within flour supplemented with buckwheat flour were nonsignificant, DDT rose from $1 \mathrm{~min}$ to $1.2 \mathrm{~min}$ when buckwheat flour concentration was low, increasing buckwheat flour, increased DDT from $5.50 \mathrm{~min}$ to $10.20 \mathrm{~min}$. The highest value for dough development time $(10.20 \mathrm{~min})$ was found in $\mathrm{T}_{5}(50 \%$ buckwheat flour), while the lowest value $(5.50 \mathrm{~min})$ was found in $\mathrm{T}_{1}$ (Wheat Flour) and the DDT ranged from 1 minute to 1.2 minutes when portions of buckwheat flour added from $1 \mathrm{gm}$ to $20 \mathrm{gm}$ in $100 \mathrm{gm}$ flour.

The time for dough stability was observed in the range of $7.10 \mathrm{~min}$ to $11.20 \mathrm{~min}$. The highest was observed in $\mathrm{T}_{2}$ while the lowest value was noticed in $\mathrm{T}_{0}$. Nikolic et al. (2011) reported that the stability of dough for composite flour dough was considerably higher (4.6 min) in the dough with buckwheat flour portion of $30 \mathrm{~g} / 100 \mathrm{~g}$, where it was only 0.3 minutes in the dough with wheat flour only. Wet and dry gluten of supplemented buckwheatflourwas significant $(p<0.05)$ and decreased with increasing ratio of buckwheat flour. The dry gluten content of flours decreased with an increase in buckwheat supplementation levels as shown in Table 2. A similar trend was observed in previous studies. Gavurnakova et al. (2011) reported that the gluten content of composite flours decreased significantly with a gradual increase in buckwheat flour ratio and a gradual decrease in gluten proteins of buckwheat.

\section{Proximate analysis of buckwheat supplemented flour}

Proximate analysis of buckwheat supplemented flour (moisture, fats, fiber, protein) was carried out to find the quality of flour for further use. The mean values showed that buckwheat flour contains $12.0 \%$ moisture, $9.08 \%$ crude proteins, $1.01 \%$ ash, $0.4 \%$ dry gluten, and $0.98 \%$ wet gluten. The values were in close conformity with the findings of different researchers, who stated that buckwheat flour contain 7.08 to $11.03 \%$ moisture, 11 to $18.01 \%$ protein content, 1.1 to $3.5 \%$ crude fats, 0.6 to $1.7 \%$ crude fiber, 1.3 to $2.8 \%$ ash and 64 to $73 \%$ NFE (Fessas et al., 2008). Buckwheat flour contains about 8-19 \% proteins which depend on variety, fertilizers and pesticides used (Fornal, 1999). The proximate analysis shows us that in future studies how the quality of product will be made which affects the physical, chemical and sensory analysis of products.

\section{Cooking analysis of pasta}

Cooking behavior was checked that how much time is required for boiling and loss of solids particles during cooking (Figure 1). The results for cooking parameters are detailed below. The cooking time of different buckwheat supplemented pasta samples were significantly $(p<0.05)$ higher $(21.00$ minutes $)$ in $\mathrm{T}_{0}$ and significantly $(p<0.05)$ lower time was recorded in $\mathrm{T}_{5}$. According to Mustafa et al. (1986) buckwheat contains protein other than wheat and durum wheat flour and buckwheat flour is gluten-free which requires less water as compared to gluten-containing flour. The loss of solids in different buckwheat supplemented pasta was significant $(p<0.05)$. Higher matter loss (4.30\%) was observed in $\mathrm{T}_{5}$ and lower matter loss (1.67\%) was recorded in $\mathrm{T}_{0}$. The loss of solids was higher in pasta samples containing $50 \%$ buckwheat, 
as compared to Wheat Flour pasta. According to the study of Steadman, Burgoon, Lewis, buckwheat flour bran contains about $11.9 \%$ dietary fiber which leaches out from pasta during cooking (Manthey et al., 2004) the high matter loss in all the treatments was observed in gluten free samples.

The increase in weight in different buckwheat supplemented pasta samples was significantly different among each other. Higher weight increase (38.49\%) was observed in $\mathrm{T}_{5}$ and a lower weight increase $(20.77 \%)$ was recorded in $\mathrm{T}_{0}$. The higher weight increase was noticed in the buckwheat flour pasta then that of other flour pasta, which depends upon different factors like non-starch polysaccharide content of BW which is responsible to have high water absorption (Izydorczyk et al., 2014). The unusual conformation of buckwheat starch granules, which are smaller, with a more irregular structure, and contain more amorphous areas than those of wheat; and the disruption in the protein matrix, promoting water absorption (Acquistucci and Fornal, 1997; Qian et al., 1998).

Proximate analysis of buckwheat supplemented pasta

Moisture content: The moisture content of buckwheat supplemented pasta was significantly $(p<0.05)$ higher and decreased significantly with gradual increase in buckwheat flour addition (Table 3). Higher moisture content was found in $T_{0}$ and the lower moisture content was found in $T_{5}$. The above difference in the moisture \% may be due to the fact that a gradual decrease in protein content may decrease moisture levels because of low water absorption (Mustafa et al., 1986). During the time period of two months a decreasing and significantly affected variation was found among the different pasta samples (Table 4) The gradual decrease may be due to increasing temperature in the month of June and July and low relative humidity during the storage period (Alamprese et al., 2007). He also reported in his study that due to low moisture microbial proliferation was also low and it increases the shelf life of food products.

Ash content: The mean values for treatments and storage intervals are placed in Table 3. The mean values for ash content among treatments differed significantly $(p<0.05)$. The highest ash content was found in $\mathrm{T}_{5}$ (50\% buckwheat) and the lowest ash content was observed in $\mathrm{T}_{0}(0 \%$ buckwheat). The increase in ash content in buckwheat supplemented pasta was due to an increase in buckwheat flour content because buckwheat flour possesses more ash content as compared to wheat flour. Baljeet et al. (2010) studied that supplementation of buckwheat flour increases ash content. Bilgicli (2009) reported that ash content increases due to supplementation of buckwheat flour in Turkish noodles. Some researchers reported the gradual increase in the ash (\%) content of altered cereal produces with the addition of buckwheat granulating (milling) products. During the storage period of two months, the non-significant effect was recorded for ash content (Table 4).

Fat content: Crude fats in buckwheat supplemented pasta was significantly $(p<0.05)$ affected by the variation in supplementation. The highest value was observed in $\mathrm{T}_{5}$ (50\% buckwheat) and the lowest value was found in $\mathrm{T}_{0}$ ( $0 \%$ buckwheat). According to the study of Bilgicli (2009), buckwheat flour has more fats content than wheat flour. The fats contents were increased in the treatments with the gradual increase in supplementation of buckwheat flour. Buckwheat grain contains many valuable nutrients such as proteins, fats, polysaccharides, vitamins, minerals, fiber, and polyphenols (Kreft et al., 2010). A significant $(p<0.05)$ decrease was observed in the buckwheat supplemented pasta during the storage period of two months as summarized in Table 4. From 0 day to 60 days of the interval a decreasing data were recorded. The decreased amount of crude fats may be due to occurrence of rancidity in the flour and after that subsequently in the pasta. The activation of lipase enzyme activity also decreases the fats content, he decreased amount of fat content in pasta might be due to occurrence of rancidity in flour and subsequently in pasta or it may be due to the activation of lipase enzymes activity in flour, which splits the fat into free fatty acids and glycerol which happens in the presence of moisture content as due to some environmental factors like heat and light (Khan et al., 2012). According to the study of Moroni et al. (2012) who reported about the decreasing of fats contents in gluten-free food and ready to serve food products made up of buckwheat from which they stated that the addition of buckwheat flour might show a gradual increase in crude fats content. A significant change and decrease of crude fats content in fortified and unfortified flour and buckwheat flour product for two months period of storage (Akhtar et al., 2005). 
Table 1: Ratio of flours for proximate analysis and pasta production.

$\mathrm{T}_{0}=85 \%$ Wheat Flour $+15 \%$ Durum Wheat Semolina

$\mathrm{T}_{1}=75 \%$ Wheat Flour $+15 \%$ Durum Wheat Semolina $+10 \%$ Buckwheat Flour

$\mathrm{T}_{2}=65 \%$ Wheat Flour $+15 \%$ Durum Wheat Semolina $+20 \%$ Buckwheat Flour

$\mathrm{T}_{3}=55 \%$ Wheat Flour $+15 \%$ Durum Wheat Semolina $+30 \%$ Buckwheat Flour

$\mathrm{T}_{4}=45 \%$ Wheat Flour $+15 \%$ Durum Wheat Semolina $+40 \%$ Buckwheat Flour

$\mathrm{T}_{5}=35 \%$ Wheat Flour $+15 \%$ Durum Wheat Semolina $+50 \%$ Buckwheat Flour

Table 2: Rheological study of Buckwheat supplemented flours.

$\begin{array}{lllllll}\text { Treatments } & \text { Moisture (\%) } & \text { Wet Gluten (\%) } & \text { Dry Gluten (\%) } & \text { WA (\%) } & \text { DDT (minutes) } & \text { DS (minutes) } \\ \mathrm{T}_{0} & 13.350 \pm 1.15 \mathrm{a} & 24.058 \pm 0.59 \mathrm{a} & 9.8406 \pm 0.09 \mathrm{a} & 56.40 \pm 0.11 \mathrm{c} & 5.50 \pm 0.10 \mathrm{f} & 7.10 \pm 0.10 \mathrm{a} \\ \mathrm{T}_{1} & 13.199 \pm 0.04 \mathrm{a} & 19.707 \pm 0.64 \mathrm{~b} & 7.1537 \pm 0.12 \mathrm{~b} & 55.10 \pm 0.10 \mathrm{~d} & 7.40 \pm 0.10 \mathrm{~d} & 6.2 \pm 0.09 \mathrm{~b} \\ \mathrm{~T}_{2} & 13.264 \pm 0.04 \mathrm{a} & 19.333 \pm 0.58 \mathrm{~b} & 4.9423 \pm 0.12 \mathrm{c} & 55.20 \pm 0.12 \mathrm{~d} & 7.60 \pm 0.10 \mathrm{c} & 4.3 \pm 0.06 \mathrm{c} \\ \mathrm{T}_{3} & 12.853 \pm 0.05 \mathrm{ab} & 14.119 \pm 0.76 \mathrm{c} & 3.6413 \pm 0.12 \mathrm{~d} & 56.30 \pm 0.12 \mathrm{c} & 6.10 \pm 0.10 \mathrm{e} & 3.6 \pm 0.09 \mathrm{~d} \\ \mathrm{~T}_{4} & 12.263 \pm 0.04 \mathrm{~b} & 12.203 \pm 0.69 \mathrm{~d} & 3.0280 \pm 0.24 \mathrm{e} & 57.93 \pm 0.15 \mathrm{~b} & 9.10 \pm 0.10 \mathrm{~b} & 1.7 \pm 0.10 \mathrm{e} \\ \mathrm{T}_{5} & 12.098 \pm 0.05 \mathrm{~b} & 8.808 \pm 0.97 \mathrm{e} & 2.4806 \pm 0.22 \mathrm{f} & 58.80 \pm 0.10 \mathrm{a} & 10.20 \pm 0.10 \mathrm{a} & 1.3 \pm 0.07 \mathrm{f}\end{array}$

Table 3: Proximate analysis of buckwheat supplemented pasta.

$\begin{array}{lllllll}\text { Sample } & \text { Moisture } & \text { Ash } & \text { Fiber } & \text { Fats } & \text { Protein } & \text { NFE } \\ \mathrm{T}_{0} & 4.63 \pm 0.04 \mathrm{a} & 0.88 \pm 0.02 \mathrm{f} & 0.01 \pm 0.00 \mathrm{f} & 1.94 \pm 0.05 \mathrm{e} & 6.14 \pm 0.04 \mathrm{e} & 69.39 \pm 0.04 \mathrm{a} \\ \mathrm{T}_{1} & 4.46 \pm 0.07 \mathrm{~b} & 1.53 \pm 0.01 \mathrm{e} & 1.07 \pm 0.00 \mathrm{e} & 2.27 \pm 0.03 \mathrm{~d} & 5.22 \pm 0.04 \mathrm{f} & 68.93 \pm 0.07 \mathrm{~b} \\ \mathrm{~T}_{2} & 4.26 \pm 0.06 \mathrm{c} & 1.59 \pm 0.01 \mathrm{~d} & 1.38 \pm 0.00 \mathrm{~d} & 2.58 \pm 0.04 \mathrm{~b} & 6.44 \pm 0.04 \mathrm{~d} & 67.29 \pm 0.06 \mathrm{c} \\ \mathrm{T}_{3} & 4.14 \pm 0.06 \mathrm{~d} & 1.64 \pm 0.03 \mathrm{c} & 1.85 \pm 0.05 \mathrm{c} & 2.57 \pm 0.04 \mathrm{~b} & 7.59 \pm 0.05 \mathrm{c} & 65.04 \pm 0.06 \mathrm{~d} \\ \mathrm{~T}_{4} & 4.01 \pm 0.06 \mathrm{e} & 1.68 \pm 0.02 \mathrm{~b} & 2.27 \pm 0.03 \mathrm{~b} & 2.46 \pm 0.04 \mathrm{c} & 7.73 \pm 0.05 \mathrm{~b} & 60.75 \pm 0.06 \mathrm{e} \\ \mathrm{T}_{5} & 3.80 \pm 0.04 \mathrm{f} & 1.72 \pm 0.04 \mathrm{a} & 2.64 \pm 0.04 \mathrm{a} & 3.01 \pm 0.06 \mathrm{a} & 8.93 \pm 0.03 \mathrm{a} & 57.78 \pm 0.04 \mathrm{f}\end{array}$

Table 4: Effect of storage on buckwheat supplemented pasta.

$\begin{array}{lllllll}\text { Days Interval } & \text { Moisture } & \text { Ash content } & \text { Fiber } & \text { Fats } & \text { Protein } & \text { NFE } \\ 0 & 4.33 \pm 0.04 \mathrm{a} & 1.54 \pm 0.02 \mathrm{a} & 1.56 \pm 0.02 \mathrm{a} & 2.55 \pm 0.00 \mathrm{a} & 7.14 \pm 0.04 \mathrm{a} & 62.21 \pm 0.02 \mathrm{e} \\ 15 & 4.29 \pm 0.07 \mathrm{a} & 1.50 \pm 0.04 \mathrm{a} & 1.54 \pm 0.02 \mathrm{a} & 2.49 \pm 0.06 \mathrm{c} & 7.07 \pm 0.07 \mathrm{~b} & 63.86 \pm 0.11 \mathrm{~d} \\ 30 & 4.22 \pm 0.06 \mathrm{a} & 1.50 \pm 0.01 \mathrm{a} & 1.53 \pm 0.01 \mathrm{a} & 2.40 \pm 0.09 \mathrm{~d} & 7.00 \pm 0.07 \mathrm{c} & 67.17 \pm 0.12 \mathrm{c} \\ 45 & 4.16 \pm 0.05 \mathrm{a} & 1.49 \pm 0.01 \mathrm{a} & 1.53 \pm 0.01 \mathrm{a} & 2.34 \pm 0.06 \mathrm{e} & 6.95 \pm 0.05 \mathrm{~d} & 66.11 \pm 0.11 \mathrm{~b} \\ 60 & 4.08 \pm 0.05 \mathrm{a} & 1.49 \pm 0.01 \mathrm{a} & 1.52 \pm 0.02 \mathrm{a} & 2.54 \pm 0.10 \mathrm{~b} & 6.90 \pm 0.05 \mathrm{e} & 66.97 \pm 0.09 \mathrm{a}\end{array}$

Fibre content: The mean values for crude fiber differed significantly $(p<0.05)$ among treatments and are given in Table 3. The highest fiber content was found in $\mathrm{T}_{5}$ (50\% buckwheat flour) and the lowest fiber content was observed in $\mathrm{T}_{0}$ ( $0 \%$ buckwheat). Bonafaccia et al. (2003) reported that grain of buckwheat is a rich source of fiber with a high biological value also. Baljeet et al. (2010) studied buckwheat flour and found the significant effect of fiber. At the time of storage of two months, a significant effect of crude fiber content was observed. From 0 day to 60 days of analysis the crude fiber content was decreased as given in Table 4 . Anjum et al., 2006 observed in his experiments that change in the effect of crude fiber is very low during storage. He also found non-significant changes in crude fiber during a storage period of buckwheat flour.

Protein content: A gradual significant increase in the protein content was observed during storage. The means for crude protein content of buckwheat supplemented pasta is present in Table 3. The highest crude protein content was observed in $T_{5}$ (50\% buckwheat) and the lowest protein content was observed in $\mathrm{T}_{0}$ ( $0 \%$ buckwheat). Crude protein content was increased with the gradual increase in supplementation of buckwheat flour in the treatments. 
Increasing of buckwheat flour increased the protein content because buckwheat grain and flour have high protein contents than other wheat flour.

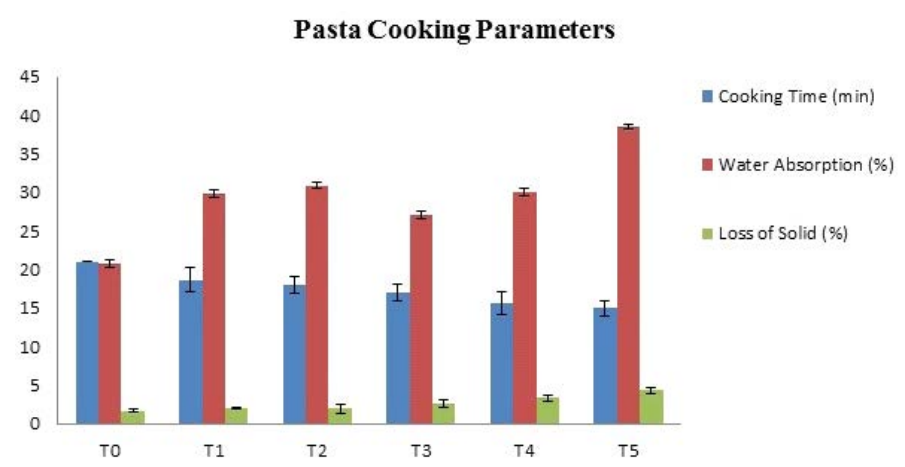

Figure 1: Pasta Cooking Quality Paprameters; $T_{0}: 85 \%$ Wheat Flour $+15 \%$ Durum Wheat Semolina $T_{1}: 75 \%$ Wheat Flour $+15 \%$ Durum Wheat Semolina $+10 \%$ Buckwheat Flour T: $65 \%$ Wheat Flour $+15 \%$ Durum Wheat Semolina $+20 \%$ Buckwheat Flour T: $55 \%$ Wheat Flour $+15 \%$ Durum Wheat Semolina $+30 \%$ Buckwheat Flour T: 45\% Wheat Flour + 15\% Durum Wheat Semolina $+40 \%$ Buckwheat Flour $T_{5}: 35 \%$ Wheat Flour $+15 \%$ Durum Wheat Semolina $+50 \%$ Buckwheat Flour.

From the study of Baljeet et al. (2010) who also utilized buckwheat flour in cookies and noodles and reported a gradual increase of crude protein content which was from $5.0 \%$ to $7.0 \%$. (Bejosano and Corke, 1998) they all also reported the range of crude protein from 9.7 to $15 \%$ in buckwheat flour. During the storage of two months of buckwheat supplemented pasta decreasing protein content (\%) was recorded as shown in Table 4. At the start of the experiment, crude protein content was recorded $7.64 \%$ and on the termination of the experiment crude protein was recorded $7.40 \%$. The reason for decreasing the crude protein contents in buckwheat supplemented pasta was due to proteolytic activity of enzymes present. The degradation of protein content is done by protease enzymes that convert crude proteins into amino acids and leading to a decrease in protein content. Shahzadi et al. (2005) also recorded a decrease in the protein content of chapattis made up of composite flour during storage.

\section{Sensory analysis of buckwheat supplemented pasta}

The sensory evaluation of the buckwheat supplemented pasta on the basis of their color, taste, and texture showed significant differences among different treatments (Table 5). Scores assigned to supplemented pasta on the basis of their color, taste and texture ranged from 9.00 to $5.00,8.66$ to 6.33 and 8.33 to 5.66, respectively, among different buckwheat supplemented pasta samples. The buckwheat

supplemented pasta has been shown in Figure 2. The result revealed that the color of pasta was different from each other and the scores vary from 5 to 9 points. The highest scores ( 9$)$ was given to $\mathrm{T}_{0}(0 \%$ buckwheat) and the lowest scores (5) was given to $\mathrm{T}_{5}$ (50\% buckwheat). The color of buckwheat supplemented pasta was significantly different from each other as the increasing amount of buckwheat flour. The lowest scores were exhibited by $\mathrm{T}_{5}$ which might be due to the dark brown color of the buckwheat flour. However, Chillo et al. (2008) developed spaghetti from durum wheat with buckwheat supplementation and that spaghetti showed similar sensory result for the spaghettis he made from durum wheat semolina. The mean scores for sensory analysis for the texture of buckwheat pasta have been given in Table 5. The result revealed that the texture of the pasta was different from each other which differed from 5.6 to 8.33 scores. The highest scores (8.33) was given to $T_{0}$ and lower scores (5.6) were given to $T_{5}$. The main problem of any product is its bad texture which degrades the product sensory quality, due to its disintegration during cooking. In the present study, sensory characteristics for taste of pasta were different from each other which result a change from 6.33 to 8.66 scores. The significantly highest scores (8.66) were given to $\mathrm{T}_{0}$ and significantly lowest scores (6.33) were given to $T_{5}$.

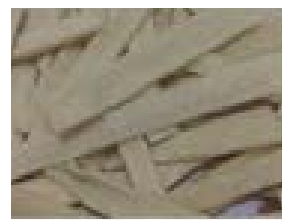

$\mathrm{TO}(0 \% \mathrm{BW})$

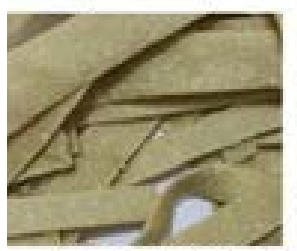

$\mathrm{T} 3(30 \% \mathrm{BW})$

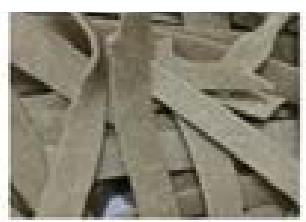

$\mathrm{T} 1(10 \% \mathrm{BW})$

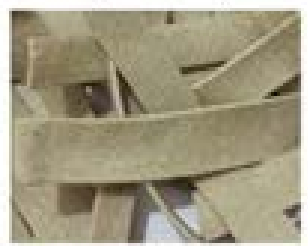

$\mathrm{T} 4(40 \%$ BW $)$

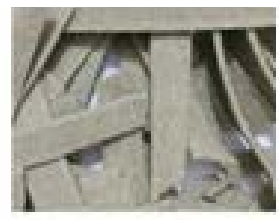

$\mathrm{T} 2(20 \% \mathrm{BW})$

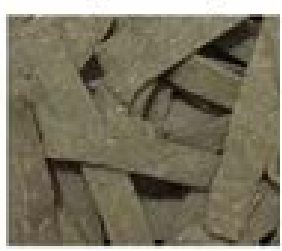

T5(50\% BW)

Figure 2: Buckwheat supplemented pasta

Table 5: Sensory analysis for buckwheat supplemented pasta.

$\begin{array}{llll}\text { Treatments } & \text { Color } & \text { Taste } & \text { Texture } \\ \mathrm{T}_{0} & 9.00 \pm 0.00 \mathrm{a} & 8.66 \pm 0.58 \mathrm{a} & 8.33 \pm 1.15 \mathrm{a} \\ \mathrm{T}_{1} & 8.66 \pm 0.58 \mathrm{a} & 8.66 \pm 0.00 \mathrm{a} & 7.66 \pm 0.58 \mathrm{ab} \\ \mathrm{T}_{2} & 7.33 \pm 0.58 \mathrm{~b} & 8.00 \pm 0.58 \mathrm{ab} & 6.66 \pm 1.15 \mathrm{bc} \\ \mathrm{T}_{3} & 7.00 \pm 1.00 \mathrm{~b} & 7.33 \pm 0.58 \mathrm{~b} & 6.33 \pm 0.58 \mathrm{bc} \\ \mathrm{T}_{4} & 6.66 \pm 0.58 \mathrm{~b} & 6.33 \pm 0.58 \mathrm{c} & 6.33 \pm 0.58 \mathrm{bc} \\ \mathrm{T}_{5} & 5.00 \pm 0.00 \mathrm{c} & 6.33 \pm 0.58 \mathrm{c} & 5.66 \pm 0.58 \mathrm{c}\end{array}$

September 2020 | Volume 33 | Issue 3 | Page 540 
In the panel, the judges scored between 6 to 8 , which is placed in like and like moderately. As the concentration of buckwheat increase in the pasta, the liking taste retarded gradually. This might be due to the fact that people consume whole wheat flour food products and the taste of buckwheat suddenly changed, as well as it may also be the reason for color and texture change. Another reason that explains the low acceptance of pasta with higher supplementation of buckwheat can be attributed to higher content of ash in pasta. According to the study of Kim et al. (2004), flour having high ash content signifies that there are some unwanted materials presents such as bran, which may be reflected in the low textural quality. Baljeet et al. (2010) reported in his study that low scores for sensory characteristics might be due to flavonoid compound (rutin) which gave a bitter taste in buckwheat flour.

\section{Conclusions and Recommendations}

The addition of buckwheat flour in formulation of pasta had significant effects on color value, cooking quality, sensory and rheological properties of pasta. As the supplementation ratio of buckwheat flour increased in pasta, the weight, ash, fiber, fats and protein content also increased. The buckwheat flour negatively affected cooking and color scores of pasta. As a result of the sensory evaluation, the overall acceptance of pasta was found best in pasta supplemented with 30\% buckwheat flour. It can be concluded that buckwheat flour addition improved the nutritional quality of pasta but 40 and $50 \%$ BWF addition level adversely affected color and sensory properties.

\section{Author's Contribution}

Anwar Ahmad and Naeem Khalid gave the idea and designed the study. Tanveer Sultan performed experiments in labs and wrote the manuscript. Aqsa Qayyum and Amer Mumtaz supervised the experiments in the lab and reviewed the manuscript.

\section{Conflict of interest}

The Authors have declared no conflict of interest.

\section{References}

AACC. 2000. Approved methods of american association of cereal chemists international. St.
Paul, MN: Am. Assoc. Cereal Chem. Int., Inc. Acquistucc, R. and J. Fornal. 1997. Italian buckwheat (Fagopyrum esculentum) starch: physicochemical and functional characterization and in vitro digestibility. Food/ Nahrung 41: 281-284.

Ahmed, A., N. Khalid, A. Ahmad, N. Abbasi, M. Latif and M. Randhawa. 2014. Phytochemicals and biofunctional properties of buckwheat: A review. J. Agric. Sci., 152(3): 349-369. https:// doi.org/10.1017/S0021859613000166

Akhtar S, F. M. Anjum, S.U. Rehman and A. Ahmed. 2005. Impact of storage on phytate contents of fortified whole wheat flour. Pak. J. Food Sci., 15: 07-11.

Akubor, P.I. and G.I.O. Badifu. 2001. Chemical composition, functional properties and baking potential of African bread fruit kernel and wheat flour blends. Int. J. Food Sci. Technol., 39: 223-229. https://doi.org/10.1046/j.09505423.2003.00768.x

Alamprese, C., E. Casiraghi and M.A. Pagani. 2007. Development of gluten-free fresh egg pasta analogues containing buckwheat. Eur. Food Res. Technol. 225(2): 205-213. https:// doi.org/10.1007/s00217-006-0405-y

Anjum, F.M., M.I. Khan, M.S. Butt, S. Hussain and M. Abrar. 2006. Functional properties of soy hulls supplemented wheat flour. Nutr. Food Sci., 36(2): 82-89. https://doi. org/10.1108/00346650610652286

Baljeet, S.Y., B.Y. Ritika and L.Y. Roshan, 2010. Studies on functional properties and incorporation of buckwheat flour for biscuit making. Int. Food Res. J. 17(4):1067-1076.

Bejosano, F.P. and H. Corke. 1998. Effect of Amaranthus and buckwheat proteins on wheat dough properties and noodle quality. Cereal Chem.75(2):171-176.https://doi.org/10.1094/ CCHEM.1998.75.2.171

Bilgiçli, N., 2009. Effect of buckwheat flour on chemical and functional properties of tarhana. LWT-Food Sci. Technol. 42(2): 514-518. https://doi.org/10.1016/j.lwt.2008.09.006

Bonafaccia, G., M. Marocchini and I. Kreft. 2003. Composition and technological properties of the flour and bran from common and tartary buckwheat. Food Chem. 80(1): 9-15. https:// doi.org/10.1016/S0308-8146(02)00228-5

Chillo, S., J. Laverse, P. Falcone, A. Protopapa and M.D. Nobile. 2008. Influence of the addition 
of buckwheat flour and durum wheat bran on spaghetti quality. J. Cereal Sci. 47(2): 144-152. https://doi.org/10.1016/j.jcs.2007.03.004

Ciacci, C., P. Ciclitira, M. Hadjivassiliou, K. Kaukinen, J.F. Ludvigsson, N. McGough, G.L. Swift. 2015. The gluten-free diet and its current application in coeliac disease and dermatitis herpetiformis. United Eur. Gastroenterol. J. 3(2): 121-135. https://doi. org/10.1177/2050640614559263

Dietrych-Szostak, D. and W. Oleszek. 1999. Effect of Processing on the flavonoid content in Buckwheat (Fagopyrum e sculentum Möench) grain. J. Agric. Food Chem. 47(10): 4384-4387.

Fabjan,N.,J.Rode,I.J.Košir,Z.Wang,Z.Zhang and I. Kreft. 2003. Tartary buckwheat (Fagopyrum tataricum Gaertn.) as a source of dietary rutin and quercitrin. J. Agric. Food Chem., 51(22), 6452-6455.

Fessas, D., M. Signorelli, A. Pagaai, M. Mariotti, S. Jametti and A. Schirald. 2008. Guidelines for Buckwheat Enriched Bread: Thermal Analysis Approach. J. Therm. Anal. Cal. 9(1):9-10.

Fornal, L., 1999. Chemizm nasion gryki kierunki spozywczego wykorzystania. Biuletyn Naukowy. Univ. Warmia Mazury Olsztyn. 4: 7-17.

Gavurnikova, S., M. Havrlentová, L. Mendel, I. Čičová, M. Bieliková and J. Kraic. 2011. Parameters of wheat flour, dough, and bread fortified by buckwheat and millet flours. Agriculture (Polnohospodárstvo), 57, (4): 144-153.

Hatcher, D., S. You, J. Dexter, C. Campbell and M. Izydorczyk.2008. Evaluation of the performance of flours from cross-and self-pollinating Canadian common buckwheat (Fagopyrum esculentum Moench) cultivars in soba noodles. Food Chem. 107(2): 722-731. https://doi. org/10.1016/j.foodchem.2007.08.072

Izydorczyk M.S., McMillan T., Bazin S., Kletke J., Dushnicky L., Dexter J. (2014) Canadian buckwheat: A unique, useful and under-utilized crop. Canadian Journal of Plant Science, 94, pp. 509-524.

Janssen, F., A. Pauly, I. Rombouts, K.J. Jansens, L.J. Deleu and J.A. Delcour. 2017. Proteins of amaranth (Amaranthus spp.), buckwheat (Fagopyrum spp.), and quinoa (Chenopodium spp.): A food science and technology perspective. Comp. Rev. Food Sci. Food Saf. 16(1): 39-58. https://doi.org/10.1111/1541-4337.12240
Khan,N.,N.A.Qureshi,M.Nasir,G.W.Vandenberg, M.S. Mughal, A. Maqbool, M.A. Jabbar and N. Zikria. 2012. Effect of artificial feed on sensory attributes of flesh of Indian major carps (Labeo rohita, Catla catla and Cirrhinus mrigala) fed in monoculture and polyculture systems. Pak. Vet. J. 32, 349-353

Kim, S.L., S.K. Kim and C.H. Park. 2004. Introduction and nutritional evaluation of buckwheat sprouts as a new vegetable. Food Res. Int. 37(4): 319-327. https://doi.org/10.1016/j. foodres.2003.12.008

Kreft, I., K. Ikeda, S. Ikeda and B. Vombergar. 2010. The development of novel functional food products based on common and tartary buckwheat. Adv. Buckwheat Res. Proc. 11 ${ }^{\text {th }}$ Int. Symp. Buckwheat.

Larmond, E., 1977. Laboratory methods for sensory evaluation of food. Pub. 1637. Rev. Ed. Food Res. Inst. Dept. of Aric, Ottawa, Ont., Canada. Liu, Z., W. Ishikawa, X. Huang, H. Tomotake, J. Kayashita, H. Watanabe, M. Nakajoh and N. Kato. 2001. A buckwheat protein product suppresses 1, 2-dimethylhydrazine-induced colon carcinogenesis in rats by reducing cell proliferation. J. Nutr. 131: 1850-1875. https:// doi.org/10.1093/jn/131.6.1850

Manthey, F.A., S.R. Yalla, T.J. Dick, and M. Badaruddin. 2004. Extrusion properties and cooking quality of spaghetti containing buckwheat bran flour. Cereal Chem. 81(2): 232-236. https://doi.org/10.1094/ CCHEM.2004.81.2.232

Maeda, T., K. Miyake, M. Tahara and N. Morita. 2004. Substitution of buckwheat for wheat flours on processing pasta and cookie. Fagopyrum. 21: 99-103.

Moroni, A.V., E. Zannini, G. Sensidoni, E.K. Arendt. 2012. Exploitation of buckwheat sourdough for the production of wheat bread. Eur. Food Res. Technol. 235(4): 659-668. https://doi.org/10.1007/s00217-012-1790-z

Mustafa, A.I, Alwessali, M.S., SI-Busha, O.M. and AIAmia, R.H.1986. Utilization of cowpea flour and protein isolate in bakery products. Cereal Food World 31: 756-59.

Nikolić, N., M. Sakač and J. Mastilović. 2011. Effect of buckwheat flour addition to wheat flour on acylglycerols and fatty acids composition and rheology properties. LWT - Food Sci. Technol. 44(3): 650-655. https://doi.org/10.1016/j. 
lwt.2010.08.017.

Ohnishi, O., 1994. Buckwheat in Karakoram and the Hindukush. Fagopyrum. 14: 17-25.

Préstamo, G., A.Pedrazuela, E.Peñas,M.Lasunción and G. Arroyo. 2003. Role of buckwheat diet on rats as prebiotic and healthy food. Nutr. Res. 23: 803-814. https://doi.org/10.1016/S02715317(03)00074-5.

Qian,J., P. Rayas-Daurte and L. Grant. 1998.Partial characterization of buckwheat (Fagopyrum esculentum. Moench) starch. Cereal chem. 49: 490-496.

Qin, P., Q.Wang, F. Shan, Z. Hou and G. Ren.2010. Nutritional composition and flavonoids content of flour from different buckwheat cultivars. Int. J. Food Sci. Technol. 45(5): 951-958. https:// doi.org/10.1111/j.1365-2621.2010.02231.x

Rosa, C. S., R.C., Prestes, K. Tessele and M. Crauss. 2015. Influence of the different addition levels of amaranth flour and rice flour on pasta buckwheat flour. Int. Food Res. J. 22(2): 691698

Schoenlechner, R., J. Drausinger, V. Ottenschlaeger,
K. Jurackova and E. Berghofer. 2010. Functional properties of gluten-free pasta produced from amaranth, quinoa and buckwheat. Plant Food Hum. Nutr. 65(4): 339-349. https://doi. org/10.1007/s11130-010-0194-0

Shahzadi, N., M.S. Butt, S.U. Rehman and K. Sharif. 2005. Rheological and baking performance of composite flour. Int. J. Agric. Biol. 1: 100-104.

Skrabanja, V., I. Kreft, T. Golob, M. Modic, S. Ikeda, K. Ikeda and K. Kosmelj. 2004. Nutrient content in buckwheat milling fractions. Cereal Chem.81(2):172-176.https://doi.org/10.1094/ CCHEM.2004.81.2.172

Steel, R., J. Torrie and D. Dickey. 1997. Principles and procedures of statistics: A Biometrical Approach., $3^{\text {rd }}$ ed. McGraw-Hill: New York.

Steadman, K.J., M.S. Burgoon, B.A. Lewis, S.E. Edwardson and R.L. Obendorf. 2001a. Buckwheat seed milling fractions: description, macronutrient composition and dietary fibers. J. Cereal Sci., 33: 271-278. https://doi. org/10.1006/jcrs.2001.0366 